\title{
The Business of Governing: Corruption and Informal Politics in Mexico City's Markets, I 946-1958
}

\author{
INGRID BLEYNAT*
}

Abstract. This paper uses corruption in Mexico City's markets as a lens to examine state-society relations and the construction of the PRI's hegemony in post-1946 Mexico. It presents three case studies that show how some ostensibly corrupt practices supported state functioning, while others contributed to the process of party building. It demonstrates that these practices were driven by shifting social dynamics and conflicts among vendors, which operated through networks of formal and informal power. Historicising corruption illuminates the strengths and weaknesses of the Mexican state as well as the balance between co-optation and popular demands that lay behind it in this period.

Keywords: corruption, tax farming, informal politics, state building, municipal markets, vendors, Mexico City, Institutional Revolutionary Party/Partido Revolucionario Institucional

\section{Introduction}

Throughout the twentieth century Mexico City's municipal markets were hubs of corruption, informal politics and social conflict. This paper examines the links between the three in the period from the formation of the Partido Revolucionario Institucional (Institutional Revolutionary Party, PRI) in I 946 to the general elections of 1958, when the party obtained its best ever result in the Federal District. ${ }^{I}$ Market vendors were central to the PRI's

Ingrid Bleynat is at the Department of International Development, King's College London. Email: ingrid.bleynat@kcl.ac.uk.

* The author thanks Guy Geltner, Olga Gonzalez-Silen, Peter Kingstone, Andrés Mejía Acosta, Paul Segal, Louise Walker and John Womack, Jr, as well as JLAS editors and referees for their insightful comments and suggestions. I am particularly grateful to Olga and Paul, who read multiple versions of this article and significantly improved it. All errors are, of course, mine.

I The PRI replaced the popular frontist Partido de la Revolución Mexicana (Party of the Mexican Revolution, PRM), which had been established eight years earlier to gather the support of organised workers and peasants. On electoral trends and results, see: Jacqueline 
success. As members of the 'popular sector', they had joined the Confederación Nacional de Organizaciones Populares (National Confederation of Popular Organisations, CNOP) when it was created in 1943. The incorporation of the CNOP was a key innovation of the national leadership and it soon became an essential component of urban electoral machines, acting as a counter-balance to the agrarian and labour movements. ${ }^{2}$ As such, the CNOP helped sustain the political bargain behind the so-called 'Mexican miracle'.

The consolidation of the PRI required a dramatic transformation of Mexico City's markets. In I 946, the capital's 42 markets were in a dismal state. Most of them were over 40 years old and had received little maintenance. They were also insufficient to host the city's tens of thousands of vendors who, as a result, set their stalls on streets, plazas and pavements. While competing with one another, sometimes violently, many vendors agreed on the need for better urban infrastructure. The vendor movement played no small role in the state-led developmentalist drive that, by 1958, showcased the construction of 69 market halls with room for more than 29,000 vendors. ${ }^{4}$ Both this process of urban renewal and the consolidation of the PRI were conflictual and coercive. They also involved practices that can be described as corrupt

Peschard, 'Las elecciones en el Distrito Federal (1946-1970)', Revista Mexicana de Sociología, 50: 3 (July-Sept. 1988), pp. 229-46. In this period the Federal District included Mexico City, but also extended beyond it.

${ }^{2}$ In addition to vendors the CNOP included state employees, professionals, small-business owners and other self-employed groups, as well as associations of low-income residents and shantytown dwellers (colonos), youths and women. David Schers, The Popular Sector of the Partido Revolucionario Institucional in Mexico (Tel Aviv: The David Horowitz Institute for the Research of Developing Countries, Tel Aviv University, 1972), pp. I-20; Luis Javier Garrido, El partido de la revolución institucionalizada. La formación del nuevo estado en México (1928-1945) (México, DF: Siglo Veintiuno Editores, 1982), pp. 331-40; Tiziana Bertaccini, El régimen priísta frente a las clases medias, 1943-I964 (México, DF: Consejo Nacional para la Cultura y las Artes, 2009), pp. 256-66.

3 The Mexican miracle refers to a period of sustained economic growth from the 1940 s to the I 970 s characterised by policies to encourage import substitution. Between 1946 and 1958 , the period covered in this paper, real income per capita rose by an estimated average of almost 3 per cent per year. Gustavo Garza, El proceso de industrialización en la ciudad de México, I82I-1970 (México, DF: El Colegio de México, 1985), pp. 14I-3; Clark W. Reynolds, The Mexican Economy. Twentieth-Century Structure and Growth (New Haven, CT: Yale University Press, 1970), pp. I-3, 36-43, 58-64, I85-96. Data is limited, but it suggests that while real wages improved between 1946 and 1960, they remained below their pre-war level. Jeffrey L. Bortz, Los salarios industriales en México, 1939-1975 (México, DF: Fondo de Cultura Económica, 1988), pp. 266-70. More generally, for a critical assessment of the 'miracle', see: Fernando Carmona, Guillermo Montaño, Jorge Carrión and Alonso Aguilar M., El milagro mexicano (México, DF: Editorial Nuevo Tiempo, 1970).

${ }^{4}$ While the most intense market building spree took place between 1955 and 1958 , the trend continued, so that by 1966 the Department of the Federal District had built 174 market halls with capacity for over 50,000 stalls. John C. Cross, Informal Politics. Street Vendors and the State in Mexico City (Stanford, CA: Stanford University Press, 1998), pp. I64, I71. 
to the extent that they entailed the misuse of public offices to further the material and political interests of the implicated government officials, politicians and vendors.

\section{Corruption in History}

Until recently historians of Mexico rarely ventured beyond I 940. In one of the first monographs to do so, Stephen Niblo reveals the scope of corruption in Mexican mid-century politics, mining the archives for case after case of politicians involved in shady deals, outright theft, graft, kickbacks, and every other imaginable form of abuse of office and political connections for private gain. ${ }^{5}$ His findings dovetail with a current historiography on Mexico's political system of the I940s and I950s, which over the last decade has shown that the state was weaker than historians had assumed, and politics more contested. Even if repression was rampant, the system itself was no more than 'softly authoritarian'.6 Among these studies, the topic of corruption emerges time and time over. In the introduction to Dictablanda: Politics, Work, and Culture in Mexico, 1938-1968, a 2014 anthology that synthesises the state of our knowledge of Mexico during the early, golden days of the PRI, editors Paul Gillingham and Benjamin T. Smith describe the period as one of 'baroque corruption', and the terms 'corruption', 'corrupt' and 'corrupted' appear a total of 76 times throughout the volume. 7 Yet while corruption and

5 Stephen R. Niblo, Mexico in the Ig4os. Modernity, Politics, and Corruption (Wilmington, DE: SR Books, 1999), pp. 253-303. Niblo also shows that businessmen, both Mexican and foreign, were often implicated in this vast corruption.

${ }^{6}$ For one of the founding texts of this new historiography see: Jeffrey W. Rubin, Decentering the Regime: Ethnicity, Radicalism and Democracy in Juchitán, Mexico (Durham, NC: Duke University Press, 1997). One of the best introductions to this literature is Paul Gillingham, 'Maximino's Bulls: Popular Protest after the Mexican Revolution, 1940-1952', Past and Present, 206 (Feb. 2010). For other compelling examples see: Thomas Rath, Myths of Demilitarization in Postrevolutionary Mexico, 1920-1960 (Chapel Hill, NC: University of North Carolina Press, 2013); Jaime Pensado, Rebel Mexico. Student Unrest and Authoritarian Political Culture during the Long Sixties (Stanford, CA: Stanford University Press, 2013); Robert F. Alegre, Railroad Radicals in Cold War Mexico. Gender, Class, and Memory (Lincoln, NE: University of Nebraska Press, 2013); Aaron Navarro, Political Intelligence and the Creation of Modern Mexico, 1938-1954 (University Park, PA: Pennsylvania State University Press, 2010); Benjamin T. Smith, Pistoleros and Popular Movements: The Politics of State Formation in Postrevolutionary Oaxaca (Lincoln, NE: University of Nebraska Press, 2009); Tanalís Padilla, Rural Resistance in the Land of Zapata. The Jaramillista Movement and the Myth of the Pax PRIísta, 1940-1962 (Durham, NC: Duke University Press, 2008).

7 Paul Gillingham and Benjamin T. Smith (eds.), Dictablanda: Politics, Work, and Culture in Mexico, $1938-1968$ (Durham, NC: Duke University Press, 2014). Corruption appears in 12 of the volume's 16 chapters, in addition to the introduction and concluding remarks. We encounter, among others: corruption in the allocation of military contracts and militaryrun protection rackets; fraud, violence and nepotism in state politics; bitter complaints about corruption at the municipal level; corrupt labour leaders leading moralisation 
references to it are ubiquitous, the essays rarely interrogate these instances of corruption regarding their larger implications for Mexican society and politics. ${ }^{8}$

This paper refocuses this discussion with three case studies of corrupt practices in Mexico City's markets between 1946 and 1958 that help us map the PRI's institutionalisation of the city's informal politics. While they all cover behaviours that can be perceived as corrupt, what amounts to corruption is far from unambiguous. 9 According to Joseph Nye's canonical definition, modern political corruption is 'behavior which deviates from the formal duties of a public role because of private-regarding (personal, close family, private clique), pecuniary, or status gains; or violates rules against the exercise of certain types of private-regarding influence'. ${ }^{10}$ Yet this dependence on the notion of 'formal duties' seems too narrow, leading Michael Johnston to describe corruption as 'behavior seen as abusing - according to a society's legal or social standards - a public role or resource for private benefit'. Thus he allows for the possibility of different, often contradictory, and everchanging conceptions of 'society's legal or social standards'. ${ }^{\text {I }}$

Indeed, in the first case study below accusations of corruption against the head of the Markets Office reveal how the perceived 'formal duties of a

campaigns; venal sugar cooperatives' managers colluding with corrupt field inspectors; corrupt forest wardens and other forestry officials linked to crony capitalism; corrupt political bosses in charge of a corrupt agrarian reform apparatus; crime reporters using their pages to ventilate corruption and impunity among bureaucrats, policemen, prosecutors and judges; and corrupt student representatives and university authorities.

8 The exception is Benjamin T. Smith's chapter, which analyses the federal government's attempts at fiscal centralisation as key to the process to state formation. It finds that the country's mid-century fiscal system was dependent on 'low-level corruption'. Because state and municipal governments were deprived of the right to charge certain taxes, they had to resort to bribes and illegal fines and licences to fund their operations. Benjamin T. Smith, 'Building a State on the Cheap: Taxation, Social Movements, and Politics', in Gillingham and Smith (eds.), Dictablanda, pp. 255-75.

9 The debate over the meaning of corruption is far from settled. Marc Philip, 'Defining Political Corruption', Political Studies, 45 (1997), pp. 436-62; Laura S. Underkuffler, 'Defining Corruption: Implications for Action', in Robert I. Rotberg (ed.), Corruption, Global Security, and World Order (Cambridge, MA: Brookings Institution Press, 2009), pp. 27-46.

10 Joseph Nye, 'Political Corruption: A Cost Benefit Analysis', in Arnold J. Heidenheimer, Michael Johnston and Victor T. LeVine (eds.), Political Corruption: A Handbook (New Brunswick, NJ: Transaction Books, I989), p. 966.

I Michael Johnston. 'Historical Conflict and the Rise of Standards', Journal of Democracy, 2: 4 (1991), p. 49. Corruption and the preoccupation with corruption are present throughout Mexican history, but their meanings, functions and consequences are as changing as Mexican society, and specific to historical and social contexts. For an exploration of what 'corruption' signified across different regions from the colonial times to the end of the twentieth century see: Claudio Lomnitz (ed.), Vicios públicos, virtudes privadas: La corrupción en México (México, DF: CIESAS / Porrúa, 2000). This volume de-naturalises corruption, exposing it as an ever-changing but always constructed (cultural) category. 
public role' change over time. They also illustrate the weakness of the Mexican state in the 1940s, in particular its dependence on informal mechanisms of revenue collection. This case study argues that the embezzlement of market fees can be interpreted as a remnant of a system of tax farming, or the outsourcing of revenue collection to semi-autonomous agents by a state that lacked the capacity to perform this most essential function through other means. As officials sought to 'modernise' revenue collection towards the end of the decade, these practices were increasingly decried as 'immoral'.

If historicising corruption demonstrates the fluidity of public duties, it also problematises the insistence on 'private benefit'. In his analysis of the role of corruption in Mexico's political system under the PRI, Stephen Morris points out that corrupt acts can also be committed for the sake of a corporate interest, an institution, or a political organisation. ${ }^{12}$ Or as Alan Knight puts it, while government may be at the service of graft, graft may also be at the service of government. ${ }^{13}$ Morris finds that in Mexico the combination of a strong supra-constitutional presidency, extensive corporatist mechanisms and clientelistic networks weakened civil society, undermined the rule of law and cemented informality and corruption. Yet, he argues, by allowing the deployment of patronage, they also contributed to the regime's longevity. Consequently, Morris proposes a broader notion of corruption that includes any rational act by an official of the state that violates the rules of the state, even if it may support its functioning. Corruption then can be construed as 'discord or incongruence between two dimensions of a single state'. ${ }^{14}$

Morris and Knight's perspectives draw attention to the blurred lines between corruption and informal politics. The incongruences of the Mexican state stemmed from its particular blending of formal and informal institutions, which sometimes operated at the margins of legality. As Alberto Cayeros indicates, while formal institutions were highly centralised, the PRI built its legitimacy around a set of alliances with power centres outside of the state. ${ }^{15}$ Along the same lines, Andrew Selee maintains that,

${ }^{12}$ Stephen D. Morris, Corruption and Politics in Contemporary Mexico (Tuscaloosa, AL: University of Alabama Press, 1991), pp. 4-5.

${ }^{13}$ Alan Knight, 'Corruption in Twentieth Century Mexico', in Walter Little and Eduardo Posada-Carbó (eds.), Political Corruption in Europe and Latin America (New York: Palgrave Macmillan, 1996), p. 227. Within this 'systemic', system-maintaining corruption Knight distinguishes between two contrasting forms, which he calls allocative and coercive corruption, or the carrots and the sticks of Mexican politics.

${ }^{14}$ Stephen D. Morris, 'Corruption and the Mexican Political System: Continuity and Change', Third World Quarterly, 20: 3 ('The New Politics of Corruption') (June 1999), pp. 623-43.

is Alberto Díaz-Cayeros, Federalism, Fiscal Authority, and Centralism in Latin America (Cambridge: Cambridge University Press, 2006). For an account of how a transportation businessman constructed a powerful political network connecting Mexico City's corporatist structures to the governorship of the state of Guerrero, see: Michael Lettieri, 'A Model Dinosaur. Power, Personal Networks, and the Career of Rubén Figueroa', Mexican Studies/Estudios Mexicanos, 3 1: 2 (Summer 2015), pp. 305-42. 
while they were supported by clientelism, particularism and patronage, these informal networks went beyond the unequal exchange of votes for resources and favours. They also served as channels both for citizens' demands and for state agencies to deliver social programmes. ${ }^{16}$ In other words, they constituted a form of institutionalisation of the links and mediation mechanisms between state and society. ${ }^{17}$

The quintessential mediator in Mexico's historiography is the cacique, the broker, leader, or patron at the heart of these informal networks. Throughout the twentieth century, caciques operated at all levels of the political system, from the local to the national, in both rural and urban settings. ${ }^{18}$ While they facilitated social control, most caciques also enjoyed a degree of legitimacy among their clients, with cacical rivalries typically reflecting factional disputes driven by a combination of class, ethnic and cultural conflicts. ${ }^{19}$ Wil Pansters emphasises the complex, non-linear nature of caciques' relationship to the process of state formation. Some forms of cacical power virtually disappeared with the strengthening of the state, whereas others flourished as they facilitated its expansion. The rise of the

${ }^{16}$ Andrew Selee, Decentralization, Democratization, and Informal Power in Mexico (University Park, PA: Pennsylvania University Press, 20 I I). See also Daniel M. Sabet, Police Reform in Mexico. Informal Politics and the Challenge of Institutional Change (Stanford, CA: Stanford University Press, 20I2). An earlier sociological literature on urban informality argues that patronage networks fostered co-optation and dependency, the price the poor in Mexico City paid to be able to stake claims to land, shelter and services. Susan Eckstein, The Poverty of Revolution: The State and the Urban Poor in Mexico (Princeton, NJ: Princeton University Press, 1977); Alan Gilbert and Peter M. Ward, Housing, the State, and the Poor (Cambridge: Cambridge University Press, 1985). In a more recent publication on urban informality, Ananya Roy discusses informality as 'a technique of the state', a result of state action, because it is the state that decides which types of work or property are formal and which are not, and which forms of informality are allowed to thrive and which ones need to be eliminated. State attempts at managing and planning the formalisation of work and property rights create conflicts and deepen inequalities, and thus ought be seen as part of complex political struggles. Ananya Roy, 'Urban Informality. Toward an Epistemology of Planning', Journal of the American Planning Association, 71: 2 (Spring 2005), pp. I47-58; Ananya Roy and Nezar Alsayyad (eds.), Urban Informality. Transnational Perspectives from the Middle East, Latin America, and South Asia (Lanham, MD: Lexington Books, 2004).

${ }^{17}$ Mexican informal politics also took the form of camarillas, or political cliques. Merilee Grindle, 'Patron and Clients in the Bureaucracy: Carrier Networks in Mexico', Latin American Research Review, 22: I (1977), pp. 37-66; Peter H. Smith, Labyrinths of Power: Political Recruitment in Twentieth-Century Mexico (Princeton, NJ: Princeton University Press, 1979); Roderic A. Camp, 'Camarillas in Mexican Politics: The Case of the Salinas Cabinet', Mexican Studies/Estudios Mexicanos, 6: I (Winter 1990), pp. 85-107.

${ }^{18}$ Since the 1960 s cacical studies have been central to Mexican political history. Alan Knight and Wil Pansters (eds.), Caciquismo in Twentieth-Century Mexico (London: Institute for the Study of the Americas, 2005).

19 Alan Knight, 'Caciquismo in Twentieth-Century Mexico', in ibid., pp. 16-17; 33-6. 
developmentalist state in the 1940s and 1950s, in particular, created new opportunities for caciquismo. ${ }^{20}$

The second and third case studies presented in this paper explore the overlap between caciquismo, informal politics and corruption. In both, public officials exploited their positions to establish networks that linked vendor organisations to an expanding state, in the process enhancing their own political status. The second case depicts the struggle for control of the Banco del Pequeño Comercio (Bank of Small-Scale Commerce), a publicly owned bank with the mission of serving Mexico City's vendors. Guillermo Martínez Domínguez, the head of the bank's office for the promotion and organisation of credit associations, used his office and the bank's resources to favour some vendor groups over others, and to take over the bank's directorship. His cacical practices can be seen as an early attempt at facilitating the PRI's institutionalisation of vendor politics. The third case study describes the extension of this form of political management to the vendor movement throughout the Federal District, by examining the patronage politics of the head of the markets department, Gonzalo Peña Manterola. Through arbitrary allocation of stalls and particularistic deployment of repression he restructured the vendor movement and obtained vendors' political support. These corrupt practices were an essential part of the strategy that led the PRI to its electoral success in 1958 .

At first glance the cases of Martínez Domínguez and Peña Manterola support Andrew Selee's claim that informal politics fragmented popular demands by turning rights that the state should impersonally and universally enforce into negotiations for favours from political intermediaries. ${ }^{21}$ Yet what petitions from vendor organisations suggest is that vendor demands were fragmented long before these caciques encroached upon their markets. Competition over customers, over space and stalls and over subsidised loans all generated cleavages within the growing vendor movement that preceded, and shaped, the creation of informal political networks as well as the abuse of power that came with them. Corruption, then, was not necessarily the result of a demobilised civil society, as Morris suggests. ${ }^{22}$ On the contrary, organised vendors used patronage networks, clientelism and the bourgeoning party structures in struggles among themselves. While the losers in these struggles accused their opponents of corruption, to a significant extent caciques' actions were responses to the demands of other vendors. Losing sight of this can lead us to overestimate the agency of the PRI and the state, while limiting our understanding of corruption.

${ }^{20}$ Wil Pansters, 'Goodbye to the Caciques? Definition, the State and the Dynamics of Caciquismo in Twentieth-century Mexico', in ibid., pp. 360-3.

${ }^{21}$ Selee, Decentralization, pp. I $5 ; 42-3$.

${ }^{22}$ Morris, Corruption and Politics, pp. 42-56. 


\section{The Embezzlement of Market Revenues: Tax Farming as Corruption}

In 1945 Mexico City's markets were in disarray. In May that year a study by the Cámara Nacional de Comercio (National Chamber of Commerce) estimated the number of small-scale vendors in the city at no less than 70,000 . Of those, it claimed, only 2 per cent based themselves inside market halls. The rest plied their 'poor and primitive' trade in fixed, semi-fixed and portable stalls around markets and on the streets and pavements more generally. ${ }^{23}$ In a standard diatribe against vendors, the Chamber of Commerce accused them of posing a risk to public health by selling poor quality, contaminated or adulterated products and giving the city a deplorable aspect. For their part, the most active federation of market vendors, the CNOP-affiliated Federación Nacional de Comerciantes e Industriales en Pequeño (National Federation of Small-Scale Vendors and Industrialists, FNCIP), denounced the 'peasants that come to the city to fail'. This organisation informed the press that it intended to request protection from the Departamento del Distrito Federal (Department of the Federal District) against 'the disadvantageous competition from a floating mass of more than 100,000 maladjusted workers, who one day are garbage pickers or porters, and another [day] penny-vendors of fruit and trinkets'. ${ }^{24}$ The Federation's prejudices aside, while the city was growing fast, rural migrants were only part of the story; ${ }^{25}$ natural population growth implied a young population, with many children taking to peddling to provide for themselves, or to contribute to their family's income. ${ }^{26}$ More vendors meant heightened competition and increasing discontent.

23 'El problema del comercio en pequeño es de higiene', Novedades, 25 May 1945, in Archivos Económicos, Biblioteca Lerdo de Tejada (hereafter AE, BLT; NB the clippings in this collection do not include the page the articles appear in). It would suit the Chamber of Commerce to exaggerate the number in its complaints about 'unfair competition'. In this instance they harangued the government to take all necessary measures to ensure that 'all of that energy spent on small-scale trading should be employed in agricultural production and in industries, allowing commercial interests to become decent enterprises that yield true profits': ibid.

24 'El pequeño comercio en mala situación', Excélsior, i I April 1945, in AE, BLT. Vendor organisations had reasons of their own for inflating the numbers. The Department of the Federal District was the local government of Mexico City (and of the contiguous urbanisations in the Federal District). The head of the Department was appointed by the President and a member of his cabinet.

${ }^{25}$ Mexico City's population grew from I.5 million in 1940 to 2.2 million in 1950 , and 2.8 million in 1960. The Federal District's population, in turn, grew from 1.8 million in 1940 to 3.1 million in 1950 , and a staggering though not yet explosive 4.9 million in 1960 . Luis Unikel, La dinámica del crecimiento de la Ciudad de México (México, DF: Fundación para Estudios de la Población, 1972), p. 9; James B. Pick and Edgar W. Butler, Mexico Megacity (Boulder, CO: Westview Press, 1997), p. 54. According to Wayne Cornelius almost one-half of urban population growth during the 1940-60 period resulted from rural migration. Wayne A. Cornelius, Politics and the Migrant Poor in Mexico City (Stanford, CA: Stanford University Press, 1975), p. I6.

${ }^{26}$ Eileen Ford draws attention to the fact that between 1940 and 1960 children, defined as people aged 14 and under, went from 34.8 to 4 I.5 per cent of the population of the 
Growing numbers of vendors also overwhelmed an already deficient market infrastructure and highlighted the Department of the Federal District's financial and institutional limitations. In January 1947 the Director of Public Works attended the meeting of the Department's Advisory Board, the Consejo Consultivo, to discuss the works programme for Mexico City proposed by the newly-appointed Head of the Federal District, Fernando Casas Alemán. ${ }^{27}$ His intervention was sobering. He acknowledged that all urban services and infrastructure required attention, but regretted that the Department lacked funds to tackle them. One 'of the most serious problems of the city is the absence of markets fit for human use ... [but] the whole public works budget of several years would not be enough' to solve it. He estimated that while the city needed ten large and 250 small markets, no funds had been allocated to market construction in that year's plans. ${ }^{28}$

In reaction to this account, the Consejo Consultivo asked the Director of the Department's Markets Office, Íñigo Noriega, for a follow-up, including a report on his management of the city's markets. In April 1947 Noriega informed the Consejo that he could not say how many vendors there were in the city's 42 markets. Most trade took place in zonas de mercado, or market areas - in many cases the streets adjacent to market halls - where vendors set up their stall with the authorisation of local officials. ${ }^{29} \mathrm{He}$ had ordered all administrators to take a census of the zonas de mercado under their responsibility, but the task was proving difficult. In anticipation of the

Federal District, which she aptly calls a 'city of children'. Eileen Mary Ford, 'Children of the Mexican Miracle: Childhood and Modernity in Mexico City, 1940-1968', unpub. Ph.D. Dissertation, History Department, University of Illinois at Urbana-Champaign, 2008, p. 40. 27 The Consejo Consultivo was created in January 1929, following the abolition of the Ayuntamiento de la Ciudad de México, or City Council. While it would not have executive or legislative powers, the Consejo was given the mandate to collaborate with the Department of the Federal District in the management of the city, particularly in the design of policies pertaining to the provision of public services. Convening at least bimonthly, it was to be composed of 13 councillors chosen by the president from organisations representing diverse interests, the so-called fuerzas vivas de la ciudad (living forces of the city). It included three representatives of workers' unions, and one from associations of each of the following groups: small-scale merchants, small-scale industrialists, peasants, public employees (including teachers) and tenants (colonos and inquilinos). Capitalist merchants were represented by a delegate from the local Chamber of Commerce, large industrialists by a delegate from the Chamber of Industry, and the remaining three councillors represented, respectively, professionals (mostly architects and engineers), property owners and mothers' associations (asociaciones de madres de familia). Diane Davis, Urban Leviathan: Mexico City in the Twentieth Century (Philadelphia, PA: Temple University Press, 1994), pp. 65-72.

2828 Jan. 1947, Actas y Versiones del Consejo Consultivo, Archivo Histórico del Distrito Federal (hereafter AVCC, AHDF).

${ }^{29}$ For all practical purposes the zonas de mercado functioned as markets. Market administrators treated zonas de mercado as extensions of (or substitutes for) market halls, awarding licences and charging fees for stalls in these areas. 


\section{Ingrid Bleynat}

results of his enquiry, however, he had requested the printing of 45,000 extra licences, which, if issued, would bring the total to 85,000 for the Federal District as a whole. Noriega had also instructed market administrators to survey the physical state of each market, and to create a list of repairs needed. He got only a few replies, but he was aware of the urgency of the works. Most markets were old and in poor condition. Drainage systems had collapsed, pavements and metallic structures were in disarray. Several markets lacked lighting and water provision. 'It's a true catastrophe', he concluded. ${ }^{30}$ The period's developmentalism and economic growth were not yet translating into public works for the city. ${ }^{3 \text { I }}$

The following year the chaos of the city's markets would hit Noriega personally. In April I 948 he communicated to the Department's under-treasurer that he suspected the falsification of market fees receipts. The under-treasurer suggested an audit, but Noriega preferred to bring in the secret services to corroborate his suspicions instead. ${ }^{2}$ This seems to have led nowhere. Two months later, in June I948, the Department's treasury performed its own audit of the Markets Office, during which treasury officials discovered more funds than were registered on the books. The markets accountant and cashier fled the premises, located in the top floor of the Abelardo Rodríguez market. In mid-July the judiciary took over the case. ${ }^{33}$ The accountant and the cashier, who had been at large since the audit, were immediately found and incarcerated, together with the office's typist and an accountant aide. ${ }^{34}$ In the meantime Noriega was transferred to the Department's Dirección de Obras Públicas (Public Works Directorate). ${ }^{35}$ He was detained as a suspect himself in September, but released due to a lack of evidence. Then, in June I949, a year after the audit took place, Casas Alemán temporarily shut down the Markets Office; further testimonies by the former office accountant, accountant aid, Deputy Director of Markets and Head of Market Inspectors resulted in another arrest warrant against Noriega. This time he absconded, leaving the capital. The story took a dramatic turn on 3 December I949, when Noriega wrote to President Miguel Alemán to denounce 'monstrous

3023 April 1947, AVCC, AHDF.

${ }^{31}$ Enrique Cárdenas, La hacienda pública y la política económica, 1929-1958 (México, DF: El Colegio de México/Fondo de Cultura Económica, 1994).

32 Unless otherwise stated, the following account is based on 'El Peculado de mercados', Departamento del Distrito Federal. Resumen de Actividades 1949 (México, DF: [n.p.], I950), pp. 79-8 I.

33 'Investígase el fraude en mercados', La Prensa, 9 July i 948, p. 2; 'Fue consignado el fraude de mercados. La Tesorería del D.F., demandante', El Nacional, Primera Sección, is July i 948 , pp. I, 8.

34 'Guapa taquígrafa inodada en el escandaloso fraude a la oficina de mercados', La Prensa, 23 July i 948 , pp. 2, I 5 .

35 'Cambios en el Depto. del DF. Nombramientos y remociones', Novedades, i July i 948, pp. I, 8; 'Reorganización en el Departamento del D.F.', El Universal, i July i948, pp. I, Iо. 
machinations' and persecution against himself by treasury officials. This obscure episode ends with his death, allegedly by suicide, immediately thereafter. $^{36}$

Whether he misappropriated market revenue or not, Noriega was probably a scapegoat. In the aftermath of the July 1948 devaluation of the peso, the Alemán administration desperately sought ways to assuage public discontent. Accusations of currency speculation and insider trading at the highest levels put the government on the defensive. ${ }^{37}$ In addition, managing the cost of living had become politically urgent as the government suppressed organised labour's demands for higher wages, offering price controls and food subsidies instead. ${ }^{38}$ That the story about the embezzlement of market revenues first hit the headlines at just this time is unlikely to be a coincidence. Public markets, where most people made their daily purchases, exposed the government's failure to control inflation. Intelligence service agents, who began to make daily visits to the city's markets in order to monitor the public mood, left no doubt that consumers blamed corruption for high prices. They recorded interminable attacks on the government, including the president, and expressed fears that 'people were losing respect for the high office'. The public also railed against the secretaries of Finance and Economy, and above all against the Head of the Department of the Federal District, Fernando Casas Alemán, who, rumour had it, was amassing a fortune profiting from the situation. ${ }^{39}$

${ }^{36}$ The national press printed Noriega's letter to President Alemán and discussed his death extensively. See for example: 'Carta dirigida al Sr. Presidente', Novedades, 8 Dec. 1949, p. 19; 'Patético testamento', La Prensa, 8 Dec. 1949, pp. 2, 35; 'Se mató de un tiro en el corazón, ayer, el Sr. Don Íñigo Noriega', Excélsior, 8 Dec. 1949, Primera Sección, Segunda Parte, pp. 17, 19; 'Fue irrazonable el suicidio', El Universal, 9 Dec. 1949, Segunda Sección, pp. I, I 5; 'La policía tenía orden de no capturar a Í. Noriega', Excélsior, 9 Dec. 1949, Primera Sección, Segunda Parte, pp. 17, 25; 'Carta del Tesorero del Distrito', El Universal, i 1 Dec. 1949, Primera Sección, Segunda Parte, pp. 17, 25; 'La carta y el tiro', El Universal, i I Dec. I949, Cuarta Sección, Revista de la Semana, p. 3. These articles hint at the possibility of murder. Whether Noriega's demise was a political assassination, or a suicide committed to preserve his honour as his letter claimed, the Department of the Federal District's decision to publish its own account of the case probably stemmed from the outcry it caused in the city's public sphere. Noriega's full name was Íñigo Noriega Rivera. He was the son of Íñigo Noriega Laso, personal friend of Porfirio Díaz, and successful Asturian businessman responsible for the draining of the Chalco lake in the valley of Mexico. Lucía Martínez Moctezuma, Íñigo Noriega Laso, un emporio empresarial. Migración y crecimiento económico (México, DF: Cuadernos de Historia Empresarial, UAM Iztapalapa, 200I). His mother was María Rivera Ocaranza, who died in 1947. She was Noriega Laso's second wife.

37 Niblo, Mexico in the I940s, p. 272.

${ }^{38}$ Enrique C. Ochoa, Feeding Mexico. The Political Uses of Food since IgIo (Wilmington, DE: SR Books, 2002), pp. I I $2-13$.

39 Archivo General de la Nación, Dirección General de Investigaciones Políticas y Sociales (hereafter AGN, DGIPS), c. I I I, exp. I, I 5-16, 22 July 1948. While intelligence agents' reports provide a fascinating window into the period's politics, the agents' incentives to 
Organised labour also made the connection between corruption and high prices explicitly. Agents reported that in a speech at a demonstration against the high cost of living on 2 I August 1948, one Adán Nieto, on behalf of the miners' union, declared that 'the people, like myself, ask what is the cause of the increase in the cost of living, and we respond that it is caused by corrupt politicians, the usual exploiters [comerciantes hambreadores], and bad officials'. With regard to price controls, he lamented that 'unfortunately in Mexico the law only punishes the poor meat vendors, and not the real hoarders, the influential, or the president's cronies [amigazos]'..$^{\circ}$ Indeed, according to estimates, President Alemán and the top officials of his administration deposited between US\$ 500 and US $\$ 800$ million in foreign banks between 1946 and $1952 .^{41}$ In this context it would not be surprising if the head of the Markets Office were made to fall on his sword. ${ }^{42}$

Regardless of Noriega's fate, there was unquestionably something curious about market revenues: from 1930 to 1940 they had hovered around MX\$ 2.5 million annually in nominal terms, rising to a plateau of around MX\$ 3.3 million over I94I to 1946 (see Figure I) before increasing again. It seems implausible that such similar quantities of market revenue had in fact been collected in successive years, given the substantial inflation and variable levels of economic activity that characterised the period. In contrast, total nominal Federal District revenues doubled over the i930s, and more than doubled again between 1940 and 1946.43

exaggerate threats and thus raise their own profiles should not be overlooked. Also, because they were within the purview of the Secretaría of Gobernación (Secretary of the Interior), the content of the reports, especially any criticism of other high-level party and government officials, has to be read in the light of the secretary's political agenda. After all, beginning with Alemán, four of the next five presidents would be former Secretaries of the Interior. In 1948, Ruiz Cortines might have hoped to discredit Casas Alemán, who would later be his rival for the PRI's presidential nomination.

${ }^{40}$ AGN, DGIPS, c. I I I, exp. 3, I95-6, 2 I Aug. 1948.

${ }^{41}$ Laurence Whitehead, 'On Presidential Graft: The Latin American Evidence', in Heidenheimer, Johnston and LeVine (eds.), Political Corruption, p.785. For comparison, Whitehead reports that total Mexican external public debt was 509 million US dollars in I 950.

${ }^{42}$ Morris shows that presidents routinely used legal charges of corruption and ritualistic anti-corruption campaigns to garner legitimacy: Morris, Corruption and Politics, pp. $75^{-8}$, $85,88-10$ I.

43 Sound price data are unavailable, which is why the comparison of nominal market revenues with overall Federal District revenues is particularly useful. The only consumer price index available for the r 930 os is the index of food prices in Mexico City (INEGI, Estadisticas bistóricas de México 2014, table 18.13, in www.inegi.gob.mx; date of last access 6 July 2017). This shows prices increasing by 70 per cent in the 1930 s trough-to-peak, and rising five-fold from the mid-I930s to 1946. Total nominal Federal District revenues are in Luis Aboites Aguilar, Excepciones y privilegios. Modernización tributaria y centralización en México, 1922-1972 (México, DF: El Colegio de México, 2003), pp. 398-9. 
Figure I. Nominal Market Revenues, Millions of MX\$, 1930-195o

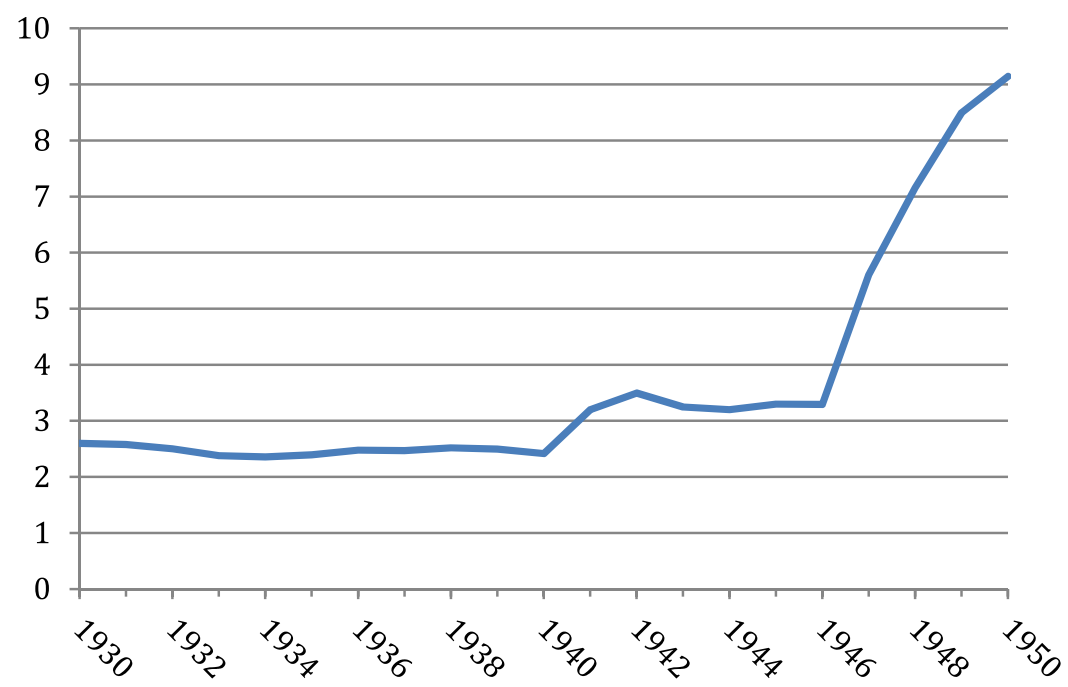

Sources: Memoria del Departamento del Distrito Federal. Del I de septiembre de 1940 al 31 de agosto de I94I (México, DF: Talleres Gráficos de la Penitenciaría, I94I), Table i I 4; Memoria del Departamento del Distrito Federal. Del I de septiembre de 1943 al 3 I de agosto de 1944 (México, DF: Departamento del Distrito Federal, I944), Table 2; Departamento del Distrito, Informe de Actividades 1947 (México, DF: DDF / Turanzas del Valle 'La Impresora', 1947), p. 76 and table titled 'Ingresos por concepto de derechos'; Departamento del Distrito Federal, Resumen de Actividades 1949 (México, DF: Departamento del Distrito Federal, 1949), p. 8 I and table titled 'Ingresos por concepto de derechos'; Departamento del Distrito, Resumen de Actividades I95I (México, DF: Departamento del Distrito Federal, I95 I), p. 35.

The departmental audit mentioned above concluded that funds had been consistently misappropriated during the previous five and a half years, and that the Markets Office still could not account for i 8 per cent of market revenue during the first semester of 1948.44 The embezzlement it uncovered, therefore, started before Noriega had become Director of Markets in December 1946, a fact that Noriega used to defend himself from the charges. For their part, the Department of the Federal District and its Treasury tried to distance themselves from the scandal. In a striking abdication of responsibility, they claimed that the Markets Office had long operated as an autonomous unit in which the Director appointed his own people to run the city's markets. They stressed that market administrators collected vendor fees each day and delivered them to the accountant in the Markets Office, only

${ }^{44}$ In total, according to the Department of the Federal District, an estimated MX\$ 5.2 million went missing during the five-and-a-half-year period they investigated - MX\$ 1.2 million more than the revenue markets produced in the second half of 1948 . 
depositing them in the Treasury several days later. As a result, there was ample opportunity for fees to go missing before they were handed over.

While the Department's portrayal of the workings of the Markets Office sounds self-serving, it was probably accurate. It also suggests a different interpretation of the practices publicly declared corrupt in 1948. In this case, the government was unable to uphold the rule of law because it did not have the administrative and institutional capacity to tax vendors, fairly allocate permits, and more generally manage markets through formal and legal means. Even a census of vendors had proved beyond reach. It therefore had to give the Markets Office space to perform these duties as it saw fit, allowing its officials to extract payments over and above their formal salaries. Put another way, the embezzlement might have formed part of an informal but established practice of tax farming. Underlying this ostensible case of corruption was a motivational mechanism used by a state otherwise unable to carry out essential functions.

If market revenue collection operated as tax farming then whatever quantity the Markets Office collected, it reported and passed to the Treasury a given expected amount, retaining the surplus as private remuneration. This would explain the otherwise puzzling stability of nominal revenues. It would also have been unexceptional. As recently as 1939 tax farming had been common at the local and state levels of government throughout Mexico. But notions of what amounted to acceptable fiscal practices were changing. That year the national Secretariat of Finance (Secretaría de Hacienda) produced a study that censured 'the immoral practice of entering into contracts, issuing concessions, or renting out to individuals the collection and administration of the most productive taxes'. ${ }^{45}$ This study indicated that these arrangements often involved nepotism, with collectors typically appropriating around 10 per cent of the tax in question. ${ }^{46}$ In official discourse, overcoming tax farming was central to the quest for fiscal 'efficiency' and 'modernisation'. ${ }^{47}$ In this light, the press coverage of the charges against Noriega can be read as part of a public debate redefining the boundaries between valid means of collecting municipal revenues and corruption. ${ }^{48}$

${ }^{45}$ Quoted in Aboites Aguilar, Excepciones y privilegios, p. 82.

${ }^{46}$ In an extreme case, in 1946 the governor of the state of México cancelled the contract for the collection of taxes on aguardientes and alcoholes (domestically produced hard liquors consumed by the popular classes), leading to an increase in annual revenues from MX\$ I 20,000 to MX\$540,000. Ibid., p. 83.

47 Ibid. Aboites Aguilar demonstrates that behind a narrative of fiscal modernisation lay attempts at centralisation. These were contested by state and municipal governments, but generally successful.

48 Pablo Piccato finds that, in this period, despite government repression and control of the press, an analysis of the police section of Mexican newspapers reveals a public debate about corruption and immorality among politicians and government officials, and to some extent a critical dialogue with the state. Pablo Piccato, 'Pistoleros, Ley Fuga, and 
Ironically, under Noriega reported nominal market revenues had begun to rise substantially from their $1940-6$ plateau of MX\$3.3 million to MX $\$ 5.6$ million in 1947 and MX\$ 7.2 million in 1948 (see Figure 1 ), representing a jump from I.9 per cent of total Federal District revenues in 1946 to 3.2 per cent in $1948 .{ }^{49}$ One possibility is that he was farming taxes more effectively than his predecessors, retaining a share for himself as his accusers claimed. Another, however, is that the rise in revenues was the result of attempts by Noriega to bring order to the 'true catastrophe' that he had found in the city's markets and to eradicate the 'immoral practices' condemned by the national Secretaría de Hacienda. In this case, Noriega represented efforts to increase the state's formal fiscal capacity. Unfortunately for him, his timing could not have been worse.

\section{The Bank of Small-Scale Commerce: Vendor Conflicts and Political Entrepreneurship as Corruption}

In a fast growing city that lacked adequate physical infrastructure and regulatory frameworks, rising vendor numbers led inevitably to conflict. Competition between vendors could be violent, often disrupting their efforts to make a living, and generating distrust among them. This made it difficult for vendors to cooperate with each other even when it would be to their mutual advantage, such as in disputes with their suppliers, with larger established merchants, and with newcomers to the city attempting to join their ranks. In this context, vendor leaders and government officials, two categories that increasingly overlapped in these years, responded to rank-and-file appeals for protection and conflict mediation. In order to advance their constituents' interests vendor leaders needed access to resources, which in some cases they obtained by misappropriating public funds. Vendor leaders may have enriched themselves along the way or increased their political status, but at least in part their actions were led by vendor demands.

Jesús Bautista, Secretary-General of the FNCIP, gave a newspaper interview in September 1949 drawing attention to the pressures affecting the vendors of La Villa de Guadalupe. In what may have been a commentary on the ongoing markets embezzlement case, he stated that La Villa's vendors deplored the voracity of the market administrators and authorities, whose first concern was their own personal gain. Bautista also complained that vendors were again

Uncertainty in Public Debates about Murder', in Gillingham and Smith (eds.), Dictablanda, pp. $32 \mathrm{I}-40$.

49 From 1946 to 1950 inflation averaged 4 per cent per year, which means that not only did market revenues grow as a share of total revenues, but there was also a significant increase in real terms. 
facing pressure to reduce the size of their stalls, noting that each time they had reduced the size of stalls in the past, the space freed up had been given to new arrivals, so that problems had grown instead of being resolved. He believed the resulting violence among vendors would subside only once the authorities built 'a large and modern market' with enough capacity for all the vendors operating in the area. 'Today the matter has taken on the proportion of a class problem.' 50

Clashes among vendors were everyday occurrences in the city's zonas de mercados. La Lagunilla Market (Figure 2), for example, spilled over the streets of Peru, Honduras, Juan Álvarez, Paraguay, Allende, and República de Chile, the plaza and streets of Comonfort, the alleys La Vaquita, Altuna, Incas, and beyond.5 ' Jesús Guzmán Olmos, on behalf of the 700 families that comprised the Unión de Comerciantes en Pequeño del Mercado de La Lagunilla (Union of Small-Scale Vendors of La Lagunilla Market), implored President Alemán to revoke permits allowing new vendors to set up stalls on Honduras Street, and to order the police to patrol the area. The vendors in his union assumed they had a standing agreement with the local authorities that the area would be protected, dating back to I 933 when they had vacated those streets and moved into the market hall on that understanding. ${ }^{52}$ Guzmán Olmos had also been lobbying, unsuccessfully, for improvements to La Lagunilla Market for quite some time. ${ }^{53}$ After two years of asking for urgent repairs for his market, he now requested President Alemán's intervention, speaking up for the city's vendors at large:

We consider it's time the Government of the Department of the Federal District create a programme to protect public market vendors, and to put a check on street vending, because the avenues of the largest city of the Republic look like Arab souks, while the city's market halls are themselves half-empty [owing to competition from the streets]. ${ }^{54}$

Conflicts spiked during religious festivities, when the influx of customers attracted more vendors. Macario Juárez, from a rival organisation, the Asociación para la Defensa de los Comerciantes en Pequeño del Mercado de la Lagunilla (Association for the Defence of Small-Scale Vendors of La Lagunilla Market), denounced Olmos and other 'dirty leaders of the La Lagunilla Market, [who] try to deprive us of our places in the annual fair of

so 'A vuelo de pluma trata importantes problemas el compañero Jesús Bautista, viejo comerciante', La Gaceta de México, Quincenal de Información y Variedades, Sept. 1949, p. 4, in Fondo Presidente Miguel Alemán Valdés, Archivo General de la Nación (hereafter MAV, AGN), c. 3 I8, exp. 433.152/A.

51 'Carece la capital de buenos mercados', Excélsior, i 2 Sept. 1945, in AE, BLT.

52 Jesús Guzmán Olmos to President Miguel Alemán Valdés, 2 June 1949, MAV, AGN, c. 286, exp. $418.5 / 2$.

53 Jesús Guzmán Olmos to President Miguel Alemán Valdés, 7 Oct. 1948, ibid.

54 Jesús Guzmán Olmos to President Miguel Alemán Valdés, 2 June 1949, ibid. 
Figure 2. La Lagunilla Market, Ig22

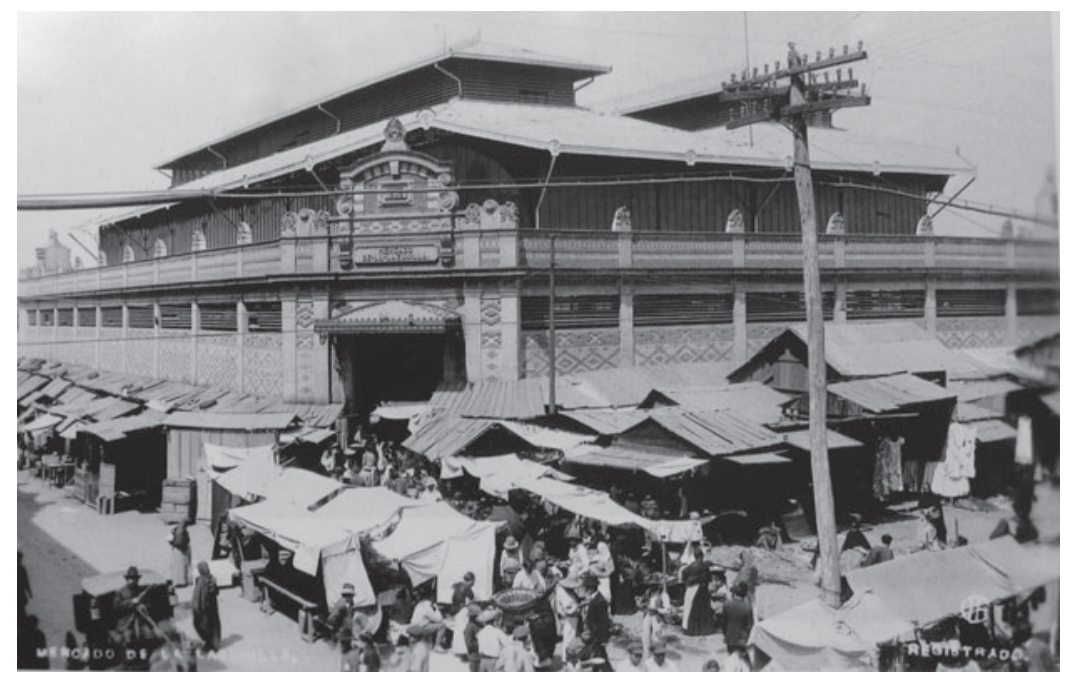

Source: AGN, Instrucción Pública y Bellas Artes, Propiedad Artística, C.I.F., PAL/8176, Inventario 3, 1922

the Three Kings, hurting our humble vendors'.55 Juárez also had a history of defending the rights of those on Honduras Street against market officials and other vendors alike. ${ }^{6} \mathrm{He}$ too begged President Alemán for his 'just protection'.57

Vendor competition and conflicts increased the need for leadership and organisation. They also led to state actors' attempts to gain control over the vendor movement. In May i950 Jesús Bautista intervened again for the National Federation of Small-Scale Vendors, writing to President Alemán with a sorry tale. He described how, from its formation in 1932, the Federation had lobbied for the creation of a Bank of Small-Scale Commerce to serve its members. After its creation in 1943 , the Federation had continued to work for Bank's stability and survival. When it was about to be dissolved in I 948 vendor leaders, Bautista among them, had met with President Alemán and obtained the MX\$3 million that saved it. But then things started to go awry for the Federation. ${ }^{58}$ In December 1948 a law modified the statutes of

55 Macario Juárez to President Miguel Alemán Valdés, I 3 Dec. I949, ibid.

56 Macario Juárez to President Manuel Ávila Camacho, 6 March 1946, MAV, AGN, c. 370, exp. 41 5.2/1; Macario Juárez to President Manuel Ávila Camacho, i I March I 946, ibid.

57 Macario Juárez to President Miguel Alemán Valdés, I 3 Dec. I949, MAV, AGN, c. 286, exp. 4 I 8.5/2.

58 Jesús Bautista to President Miguel Alemán Valdés, 2 May i950, MAV, AGN, c. 579, exp. 545.22/466. 


\section{Ingrid Bleynat}

the Bank. ${ }^{59}$ From then on, instead of lending to individual vendors, the Bank would work with bank-sponsored, market-based credit associations. In March I 949 the personnel of the Bank was changed, and Guillermo Martínez Domínguez became the head of the Office for the Promotion and Organisation of Credit Associations. And therein lay the problem: 'From that day, Mr. Martínez Domínguez has used all means available to him ... to systematically develop a web of hostilities, hatred, intrigues, and slander against this Federation, its affiliated organisations, and even against the small-scale vendors whose only crime is to be members of this Federation.' ${ }^{60}$

In particular, Bautista insisted that Martínez Domínguez had denied credit to the members of his Federation for the past 14 months, and that nobody had corrected this irregularity. He had also paid one Macario Lucero a large amount of money to 'parachute' in outside vendors ('comerciantes paracaídistas') to displace Federation members from the San Juan, Bugambilia and Lago Garda Markets. ${ }^{61}$ In a separate letter Bautista had already recently warned President Alemán that Martínez Domínguez had been using bank funds 'to create groups to support his own ambitions'. ${ }^{62}$ Now, Bautista continued, Martínez Domínguez 'is not only going to bankrupt the bank, but he is also widening the enormous division within small commerce in the Federal District, instead of attempting to harmonise and unify it'. ${ }^{63}$

The National Federation of Small-Scale Vendors and Industrialists was not alone in denouncing Martínez Domínguez. Juan de Dios Bojórquez, DirectorGeneral of the Bank by presidential appointment, had his own objections. In March 1950, within three months of taking over the Bank, he wrote to Secretary of Hacienda Ramón Beteta that he wanted to resign over a conflict with Martínez Domínguez. In accordance with the complaints of the Federation of Small-Scale Vendors, Bojórquez accused him of forming the new credit associations to benefit people who answered to him, to whom he appeared as a 'protector or leader', giving them money without safeguarding the interests of the Bank. ${ }^{64}$ The Director-General also feared the Bank was heading towards bankruptcy. Internecine conflict was not confined to vendors: the Bank's management was divided and politicking was rampant. As an organ of the state, the Bank was far from monolithic.

59 'Proyecto de ley para Bco. del Pq Comercio del DF, S.A. de C.V.', is Dec. 1948, ibid.

${ }^{60}$ Jesús Bautista to President Miguel Alemán Valdés, 2 May 1950, ibid.

${ }^{61}$ Ibid.

${ }^{62}$ Jesús Bautista to President Miguel Alemán Valdés, 4 April 1950, MAV, AGN, c. 3 I8, exp. 433.152.

${ }^{63}$ Jesús Bautista to President Miguel Alemán Valdés, 2 May 1950, MAV, AGN, c. 579, exp. 545.22/466. After 20 years at the head of the Federation of Small-Scale Vendors these were Bautista's last interventions on behalf of the city's market vendors.

${ }^{64}$ Juan de Dios Bojórquez to Secretary Ramón Beteta, 30 March 1950, MAV, AGN, c. 3 I 8 , exp. 433.152. 
For their part, the representatives of Martínez Domínguez's new credit associations refused to be blamed for the precarious financial situation of the Bank. The same day that the Director-General wrote to Beteta, they wrote to President Alemán to denounce the chaos that, they argued, Bojórquez himself had created. They claimed that he broke the law, refused to listen to them, paralysed the operations of the Bank and spent its money in absurd ways. ${ }^{65}$ A year later, in February 195 I, they renewed the offensive, attacking Bojórquez for irregularities including moving the Bank's offices to an overpriced property owned by his son. ${ }^{66}$ This time vendors threatened to 'cause a public scandal of large proportions, since each and every one of our 5,000 compañeros would be a voice in the public plazas against the immoral behaviour we are denouncing'. Furthermore, the representatives of the credit associations argued that panic would prevail and payments to the bank would be suspended, forcing it into immediate insolvency. 'We do not want to lose this patrimony you have given us. We will fight to preserve it. But we are at a dead end whose only exit is your personal intervention, and we trust you fully. ${ }^{67}$

Later that month President Alemán received another sorry tale, this time from Bojórquez. Having failed to put a stop to Martínez Domínguez's manoeuvres, the Director-General was preparing to leave the Bank, and wanted to put his complaints on record. From the beginning of its operations, Bojórquez recounted, the Bank had functioned with political aims. During its first six years the Bank had been under the control of the Federation of Small-Scale Vendors, which had almost finished the institution, leaving it with bad debts of MX\$650,000. At the end of 1948 , following the change of its statutes, the Bank began encouraging the formation of credit associations, leading to the creation of 40 of them across 40 markets. In Bojórquez's opinion, these ended up being worse than the Federation. Credit began flowing exclusively to the members of these associations, and after a year and a half of this policy, they had bad debts of around MX\$300,000.

The leaders, and even the members [of the associations], have got it into their heads that they are the owners of the Bank, and they are ready to cause scandals and demand rights, when in fact they are only debtors and its sole beneficiaries. ${ }^{68}$

His parting recommendation was to reorganise the Bank in order to make direct loans to individual vendors, and avoid dealing with vendor organisations

${ }^{65}$ Raúl Abaurre López, Eleazar T. Cruz and Arnulfo Basurto Basurto to President Miguel Alemán Valdés, 30 March 1950, ibid.

${ }^{66}$ Stephen Niblo catalogued Bojórquez's actions under 'abuse of authority', though he judges this abuse as not too blatant and rather unimaginative. Niblo, Mexico in the 1940s, p. 261 .

${ }^{67}$ Raúl Abaurre López, Eleazar T. Cruz and Arnulfo Basurto Basurto to President Miguel Alemán Valdés, 6 Feb. I95 I, MAV, AGN, c. 3 1 8, exp. 433.1 52.

${ }^{68}$ Juan de Dios Bojórquez to President Miguel Alemán Valdés, 23 Feb. 195 I, ibid. 
altogether; he wanted the Bank to treat vendors as no more than subjects of credit. ${ }^{69}$ Despite the protestations of Bojórquez and the Federation, in March I95 I Guillermo Martínez Domínguez was made the Bank's new director, to the delight of the representatives of the credit associations. ${ }^{70}$

Bojórquez's objections to how the Bank operated point to another perspective on ostensibly corrupt practices. In Mexico's weak, disorganised midcentury state, rational vendor leaders and, more generally, politicians - even those who might have been personally honest - knew that they needed their own independent treasuries if they were to respond to the demands they faced from their constituents, advance their cause, and accomplish anything administratively coherent in their own zone of responsibility. The struggles over the Bank of Small-Scale Commerce highlight the way in which conflicts among vendors translated into conflicts among and between both vendor leaders and representatives of the state; the control of public institutions and public funds was both the means by which vendor groups fought one another, and the prize that went to the winner.

Furthermore, the confrontation between Bojórquez and Martínez Domínguez epitomised the changes in the city's political landscape. Bojórquez said he wanted a purely commercial relationship with vendors. He had failed to understand that in the Mexico City of the early i950s even the Bank of Small-Scale Commerce had a more important role to play. Martínez Domínguez's strategic use of the Bank represents an early attempt to manage a divided vendor movement and institutionalise the relationship between vendors and the state.

\section{Vendors and the PRI: Political Management and State Building as Corruption}

Endemic conflict within the vendor movement posed a serious challenge to the PRI. For the party to reverse its poor performance in the Federal District's elections it had to learn to manage this movement, reshape its contours, and

69 Bojórquez proposed to offer vendors day-long loans at 0.5 per cent interest, which implied an annualised rate of 617 per cent. He defended this rate by comparing it with the loan sharks' practice of charging 5 per cent, or even 10 per cent, for 24-hour loans.

70 Raúl Abaurre López, Eleazar T. Cruz and Arnulfo Basurto Basurto to President Miguel Alemán Valdés, 8 March 1951, MAV, AGN, c. 318, exp. 433.152. By 1952 Guillermo Martínez Domínguez was a man on the up. After leaving the Bank in 1955, he became Oficial Mayor (Principal Officer) of the Comisión Federal de Electricidad (Federal Electricity Commission, CFE), later becoming its Director-General. In 1970 he was appointed Director-General of Nacional Financiera (Public Financing Agency), a post he held until 1974. His brother Alfonso rose even higher: after two stints as Federal Deputy for the Federal District (1946-9 and 1952-5), he became head of the PRI's Federal District regional committee in 1955, then Secretary-General of the CNOP between 1960 and 1965 , and head of the Federal District in 1970-1. 
gain some measure of control. ${ }^{71}$ Guillermo Martínez Domínguez's actions at the Bank of Small-Scale Commerce were part of this larger political endeavour. But from early 1952, political responsibility for the vendor movement fell primordially on the new director of the Markets Office, Gonzalo Peña Manterola. His story illustrates how picking sides in the conflicts between vendors, offering licences to some and not others, and deploying arbitrary repression were instruments used for personal advancement, as a weapon in intra-party struggles, and as part of the PRI's management of the city's electorate. These were corrupt practices in as much as they were arbitrary and particularistic, and deviated from the official rules governing markets. Yet another reading is possible: the same discretionary application of favours and extortion was key to the construction of the PRI's hegemony in the capital.

Peña Manterola began his incursions into intra-vendor politics as soon as he was appointed, quickly drawing the anger of the Federation of Small-Scale Vendors. In April 1952 Jesús Bautista's replacement as the Federation's Secretary-General, Francisco Ruvalcaba, denounced Peña Manterola for his 'policy of division and hostility towards this National Federation and its member organisations'. The Federation produced a detailed memo complaining that Peña Manterola 'openly protects elements that have no representation whatsoever', and accusing him of 'harassing our members with the purpose of dividing our organisation'. In particular this document cited the case of the Primero de Mayo Market, which the Federation claimed was left empty because vendors under the protection of Peña Manterola had encircled the premises, poaching customers and impeding access to it. Peña Manterola, it maintained, had organised these vendors to further his personal political goals. The Federation believed the same dynamic was taking place in the zona de mercado of La Dalia, and on Honduras Street in La Lagunilla. In addition, in the Beethoven and La Merced Markets, Peña Manterola had removed vendors to make room for paving work, but, once the works were completed, he refused to allow those from the Federation to retake their places, giving them instead to other vendors. The memo ended with a plea that it not be forwarded to the head of the Federal District, Peña Manterola's boss, because that would only feed the vicious circle..$^{2}$

${ }^{71}$ Like the Partido Nacional de la Revolución and the Partido Revolucionario Mexicano (National Revolutionary Party and the Party of the Mexican Revolution) before it, between 1946 and 1955 the PRI found it most difficult to control the Federal District. Both general and mid-term elections were characterised by low electoral participation and a high proportion of opposition votes compared to national figures. In the 1946 general elections, the PRI obtained only 50.34 per cent of the vote in the capital, compared to 73.52 per cent in the country at large. In the I 952 general elections, the figures were 49.01 per cent and 74.3 I per cent respectively. The PRI's performance in the city was better in the 1949 and I 955 mid-terms, but still significantly worse than the national averages. Peschard, 'Las elecciones en el Distrito Federal'.

${ }^{72}$ Francisco Ruvalcaba to President Miguel Alemán Valdés, 4 April 1952, MAV, AGN, c. I 265 , exp. 243.2/344I 6 . 
Based on these arguments, Ruvalcaba requested that President Alemán remove Peña Manterola, this being the only way to restore harmony to the city's markets. With Presidential and Congressional elections scheduled for July that year, he believed that reference to his organisation's official connections would improve his chance of a favourable resolution; he reminded Alemán that the Federation had always operated in agreement with the instructions of the PRI's Central Committee, and the CNOP, to which it belonged. He ended his letter reiterating his assurance of their collective support. Ruvalcaba's strategy made sense. Small-scale traders, and in particular the Federation, had been active in the CNOP from its creation in 1943. By the early I950s the so-called popular sector had gained influence within the party, giving the Federation the hope that by flaunting its affiliation it could sway market policy. But the gambit did not pay off. Peña Manterola would remain in charge of markets, joining the new administration under President Adolfo Ruiz Cortines' appointed Head of the Department of the Federal District Ernesto P. Uruchurtu.

The Federal District was the stronghold of the CNOP, and the growing influence of the latter in the PRI increased the city's importance for national politics. This raised the profile of the head of the Federal District, and the previous two, Javier Rojo Gómez and Fernando Casas Alemán, had entertained presidential hopes. But their office was a tricky position to hold. If the CNOP had become an indispensable component of Mexico's urban political machine by the early i 950s, it also represented the most diverse and divided of all the party sectors. Its internal conflicts would consume more than one political career. To make things worse, its rivalry with the Confederación de Trabajadores de México (Confederation of Mexican Workers, CTM) for influence within the PRI further complicated the city's politics. ${ }^{73}$ As the new head of the Federal District Uruchurtu and his Director of Markets Peña Manterola understood, vendor politics were key to the governability of the city. As vendors also understood, the higher stakes in the city increased the peril of political action and threats of disruption, as well as their potential effectiveness. ${ }^{74}$

Sociologist John Cross and historian Gary Gordon have analysed the politics of street vending during the Uruchurtu years, arguing that a combination of market construction and repression helped the government bring vendor

${ }^{73}$ María Cristina Sánchez Mejorada, Rezago de la modernidad. Memorias de una ciudad presente (México, DF: Universidad Autónoma Metropolitana, 2005), pp. 67-75; Davis, Urban Leviathan, pp. 102-5, 126, 132-6.

${ }^{74}$ Benjamin T. Smith's account of the centrality of female market vendors to Oaxaca's social movements in the I940s and early I950s also highlights their apt navigation of the state's intra-party conflicts, as well as their entanglement in caciquista struggles and their participation in oppositional politics. Smith, Pistoleros and Popular Movements, chapters 7-10. 
organisations under tighter control. 75 There is no doubt this was true. But this interpretation suggests that there was a coherent state attempting to bend vendor organisations to its will. The process, however, was more nuanced. Market politics were a core part of the city's CNOP politics. Peña Manterola, rather than representing a unified state, was actively attempting to increase his own power and that of his clique within the CNOP, and the power of the CNOP within the PRI and the government. Moreover, like Martinez Domínguez at the Bank of Small-Scale Commerce, his political manoeuvring responded to the conflicting demands of the city's vendors. Political expediency required the management of everyday competition among peddlers of tomatoes, chillies, and all manner of household necessities.

In June 1953, the then Congressman Víctor Manuel Ávila, in his role as Secretary-General of the Frente Unido de Locatarios y Comerciantes en Pequeño del Distrito Federal (United Front of Stallholders and Small-Scale Vendors of the Federal District), wrote to president Ruiz Cortines to bring to his attention another memo detailing Peña Manterola's advances, in this case, against the United Front. According to Ávila, Peña Manterola had created a rival vendor federation, 'to which he is giving all the help and support imaginable'. Congressman Ávila left no doubt of his opinion. Peña Manterola, he insisted, was trying to dissolve the United Front by slandering its leaders in the press, forcefully removing the stalls of its rank and file, imposing illegal fines, and encouraging violent confrontations. 'These scandalous practices', he claimed, 'had already caused them the loss of several organisations' ${ }^{76}$

These accusations are repeated and expanded in a document dated 2 February 1954. Its provenance is unclear, but it is part of a file in the presidential archives devoted to complaints about Peña Manterola. The first section of this document reproduced Congressman Ávila's accusations, using almost his exact words. It then broadened the scope, stating that Peña Manterola sought to dissolve all vendor federations in order to favour his own, and that to do this he played them against each other, and was willing to accuse their leaders of being enemies of the government. What is more, it related how Peña Manterola and his political clique had 'managed to impress the regional executive president of the PRI, Francisco Galindo Ochoa, who receives them and gives them preferential treatment'. Following the request of Peña Manterola, Galindo Ochoa had convoked the representatives of all vendor federations to ask them to merge into one. This unification, the document

75 Cross, Informal Politics, pp. 161-72; Gary Isaac Gordon, 'Peddlers, Pesos and Power: The Political Economy of Street Vending in Mexico City', unpubl. Ph.D. Dissertation, University of Chicago (1997), pp. 98-100.

${ }^{76}$ Congressman Víctor Manuel Ávila to President Adolfo Ruiz Cortines, 17 June 1953, Fondo Presidente Adolfo Ruiz Cortines, Archivo General de la Nación (hereafter ARC, AGN), c. $677, \exp .521 / \mathrm{I}$. 
claimed, would allow Peña Manterola to eliminate uncooperative leaders. ${ }^{77}$ Consistent with these complaints, in June 1955 secret service agents recorded that La Merced vendor leaders were calling the Director of the Markets Office 'Machiavelli Manterola'. ${ }^{7}$

The documented attacks on Peña Manterola are the traces left by vendor conflicts as they turned into political conflicts, but they should also be understood as the complaints of the losing side in the drive to manage and renovate the city. The efforts of the Director of Markets to consolidate the vendor movement under his control went hand in hand with Uruchurtu's ambitious public works programme. If the vendor movement was divided politically, it was unified in its need for more market halls and other infrastructure. One of the achievements of the Head of the Federal District was to mobilise fiscal resources in accordance with these needs. As repression and political interventions gained momentum, Uruchurtu's market building campaign reached its peak. Between 1955 and 1958 he inaugurated 69 markets with room for more than 29,000 vendors (Figure 3). In 1957 alone, a year in which the Department of the Federal District spent a quarter of its budget on the construction of 38 market halls, 20,000 stalls were built. ${ }^{79}$ This was the most intensive rate of market building that Mexico City had ever seen. In the new markets vendors were provided with refrigerators and scales, while maintenance, security, electricity and water were paid for by the city, all for a notional rent. They had day-care facilities, and vendors also received medical check-ups and were offered literacy programmes in the markets' offices $^{80}$ In other words, for the tens of thousands of organised vendors who found a place in the new markets, they represented dramatic economic progress, providing access to conveniences and social services that had seemed unattainable ten years earlier.

As the 1958 election approached vendors showed their gratitude to the government. In February, combining support for both the government's registration campaign and its efforts to reduce the cost of living, representatives of five organisations, claiming to represent 70,000 vendors, announced they would be

772 Feb. 1954, ARC, AGN, c. 1240, exp. 703.2/209.

${ }^{78}$ Report addressed to Colonel Leandro Castillo Venegas, Director Federal de Seguridad (Federal Director of Security), i I June 1955, Dirección Federal de Seguridad, Archivo General de la Nación (hereafter DFS, AGN), 30-2 I-55 H-79 L-I. The Dirección Federal de Seguridad (Federal Security Directorate, DFS) was central to the PRI's electoral dominance in this period. Navarro, Political Intelligence, p. I 86. The surveillance of market leaders by DFS agents underscores the growing importance of vendors in local and national politics. Until then intelligence-gathering efforts in markets had focused on consumers, not on vendor politics.

79 Gordon, 'Peddlers, Pesos and Power', p. 87.

${ }^{80}$ A description of the markets built between 1955 and 1966 can be found in Jane Pyle, 'The Public Markets of Mexico City', unpubl. Ph.D. Dissertation, University of Oregon (1968), chapter $\mathrm{I}$. 


\section{Figure 3. Hidalgo Market, Inauguration Day}

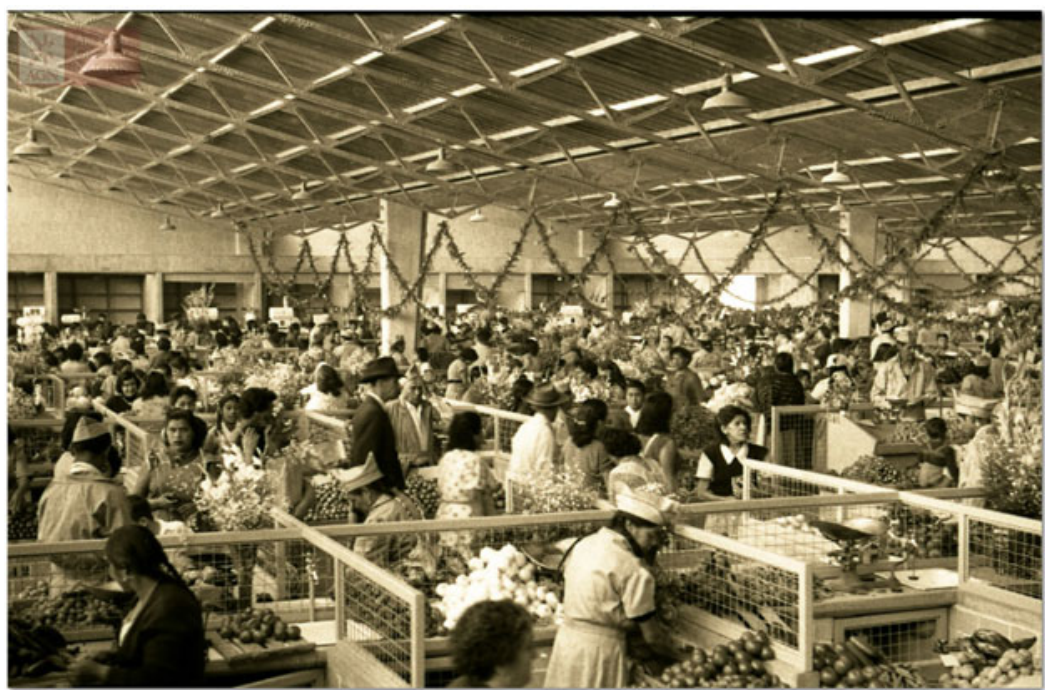

Source: AGN, Fondo Hermanos Mayo, Sección Cronológicos, Sobre 10577, November 1956

offering a io per cent discount to customers who showed them their registered voter card. ${ }^{81}$ That same day, 40,000 vendors attended a rally for the presidential candidacy of the PRI's López Mateos; they explicitly connected their backing with his promise for a continuity of Uruchurtu's policies. ${ }^{82}$ The July 1958 election would be the PRI's all-time best in the Federal District. ${ }^{83}$ The combination of Uruchurtu's leadership with Peña Manterola's politicking, including his alleged selective use of violence, favouritism in the allocation of market stalls, and other abuses of office, was a success. ${ }^{84}$ From the point of

${ }_{81}$ 'Descuento a quienes se empadronen', Excélsior, i2 Feb. 1958, in AE, BLT.

82 Cross, Informal Politics, pp. 170-I.

${ }^{83}$ The PRI won 68.59 per cent of the vote in the Federal District in 1958, having achieved between 49.01 per cent and 61.90 per cent in the previous four general elections since the PRI's creation in 1946. Peschard, 'Las elecciones en el Distrito Federal', p. 233.

${ }^{84}$ Both retained their positions for an unprecedented 14 years. This was not a small accomplishment. Yet they aspired to more. According to intelligence agents, in 1955 Uruchurtu was considered a potential presidential contender: 26 March 1955, DFS, AGN, exp. 10-26-55. Peña Manterola sought Uruchurtu's post. In July 1957 he campaigned in the press and in the city's markets with a leaflet reading 'Whoever becomes president, Peña Manterola will be regent. Long live the protector of the poor! Long live the protector of the Mexican society and family!' 22 Nov. 1957, DFS, AGN, exp. 30-25-57. Instead he was elected Deputy for the Federal District for the 44th Legislature (1958-196I) alongside his position as head of the markets department. Roderic A. Camp, Mexican Political Biographies, 19351993 (Austin, TX: University of Texas Press, 201 I), p. I 100. 
view of vendors both the pay-offs for participating in official politics as well as the costs of remaining independent had never been higher. ${ }^{85}$

\section{Conclusion}

While the mid-century Mexican state could claim significant achievements, governing was a difficult and disordered business. Corruption in Mexico City's markets was an essential part of its growing pains not just because it struggled to develop the capacity to tax vendors and manage markets, but because the process through which political entrepreneurs helped to build the state, and the organisations and institutions that supported it, involved the arbitrary allocation of stalls, bestowing of favours, withholding of services, taking of bribes, and application of extortion. To the extent that these practices furthered political ambitions and yielded material benefits we can describe them as corruption. Yet they were the means agents of the state found to extend its scope and power over the streets of the capital city.

Such corrupt practices cannot be understood in isolation from the system of informal politics that they helped create. The patron-client networks that enabled the PRI to manage the vendor movement also served as channels for vendors' voices. The politicians who incorporated the vendor movement into the burgeoning institutions of the state did not simply co-opt vendors; they acted as mediators between state and society during a delicate process of urban renewal. Exploring the overlap between informal politics and corruption problematises the dichotomy between corruption and good governance that development narratives take for granted. Sometimes corruption represented governance under hard constraints.

Political entrepreneurs mediated not just between state and society, but also between factions of the vendor movement. Much of the corruption highlighted here was driven by vendors' demands for dispute settlement and leadership in conflicts stemming from everyday competition for vending spaces, customers and public resources. It was their clash of social and material needs and the resulting divisions within the vendor movement that underlay the informal politics of the city. Put differently, the configuration of power at the local level was the result of vendors' socio-economic relations, not just of political considerations or manipulation from above. If we are to explain the country's persistent social and political ailments we need to

85 The experiences of vendors in Mexico City in the r950s contrast with those in Puebla in the I 970 and 1980 s. Sandra Mendiola finds that, from 1973 , the combination of repression and lack of investment led downtown vendors to organise independently of the CNOP, in an alliance with left-wing students. The politics of urban renewal in the age of neoliberal reform then further pushed vendors away from the PRI in the 1980s. Sandra C. Mendiola García, Street Democracy. Vendors, Violence, and Public Space in Late Twentieth-Century Mexico (Lincoln, NE: University of Nebraska Press, 2017). 
expand our focus beyond the state and towards the conflicts within society itself.

\section{Spanish and Portuguese abstracts}

Spanish abstract. Este artículo se aproxima a las relaciones entre estado y sociedad y a la construcción de la hegemonía del PRI en México a partir de 1946 mediante un análisis de la corrupción en mercados municipales de la Ciudad de México. El estudio de tres casos muestra el modo en que algunas prácticas ostensiblemente corruptas apoyaron el funcionamiento del estado, mientras que otras contribuyeron al proceso de construcción partidaria. La misma exploración devela que tales prácticas fueron activadas por dinámicas y conflictos sociales cambiantes entre los vendedores, que se desenvolvieron a través de redes formales e informales de poder. Historiar la corrupción ilumina las fortalezas y debilidades del estado mexicano así como el balance entre la cooptación y las demandas populares que existían en este periodo.

Spanish keywords: corrupción, arrendamiento de impuestos, política informal, construcción estatal, mercados municipales, vendedores, Ciudad de México, Partido Revolucionario Institucional

Portuguese abstract. Este estudo usa a corrupção nos mercados da Cidade do México como a lente através da qual serão examinadas as relações entre o estado e a sociedade e a construção da hegemonia do Partido Revolucionário Institucional - PRI - no México pós-1946. Serão apresentados três estudos de caso que demonstram o quanto algumas práticas ostensivamente corruptas alicerçaram o funcionamento do estado, enquanto outras contribuíram no processo de construção do partido. $\mathrm{O}$ estudo também demonstra como tais práticas foram motivadas por mudanças em dinâmicas sociais e conflitos entre comerciantes que operavam através de redes de poder formal e informal. Através da historicização da corrupção se revela os pontos fortes e fracos do estado Mexicano, e também o equilíbrio entre a cooptação e as demandas populares subjacentes à mesma nesse período.

Portuguese keywords: corrupção, arrecadação de impostos, política informal, construção de estado, mercados municipais, comerciantes, Cidade do México, Partido Revolucionário Institucional 